\title{
Da telenovela à realidade: violência contra mulher latina em "Woman hollering creek" de Sandra Cisneros
}

DOI: https://doi.org/10.22409/pragmatizes.v10i18.40246

\section{Heleno Álvares Bezerra Júnior ${ }^{1}$}

Resumo: Este artigo utiliza experiências penosas da protagonista de "Woman hollering creek" (uma mulher latina sem acesso à língua inglesa, vítima de violência doméstica em uma comunidade chicana no Texas, literariamente comparada à mítica figura de A Chorona) como tropo para uma reflexão sobre feminicídio na América Latina, mais especificamente no México e no Brasil. Assim sendo, a leitura ressalta o papel da telenovela como elemento midiático propulsor para a idealização do amor e o sonho de prosperidade nos EUA (American Dream); valores estes que, em nome do amor e da família heteronormativa, relegam a mulher à domesticidade, afastando-a de práticas intelectuais e do mercado de trabalho. Intensificando o olhar feminista sobre as peculiaridades da mulher latina, o texto se volta para tópicos pertinentes à Teoria Pós-colonial, e até mesmo o Feminismo Pós-colonial, com destaque para a identidade marginalizada e em trânsito, resistência cultural e interculturalidade, a intraduzibilidade linguístico-cultural bem como a prática diaspórica com vistas para melhor qualidade de vida. Considerando que a representação do inverossímil também se encontra no limiar do anglicismo e da hispanidade, o texto mostrará como leituras sobre o Fantástico, o Realismo Mágico e o Gótico Pós-colonial reforçam a adoção da figura folclórica da chorona no México como ícone de resistência, subserviência e sofrimento relegados ao corpo feminino graças às estruturas de sociedades patriarcais na América Latina.

Palavras-chave: Feminicídio; América Latina; Identidade em trânsito; Resistência cultural; Póscolonialismo.

De la telenovela a la realidad: violencia contra la mujer latina en "El arroyo de la llorona" de Sandra Cisneros

Resumen: Este artículo utiliza experiencias dolorosas de la protagonista de "El Arroyo de La Llorona" (una mujer latina sin acceso a la lengua inglesa, víctima de violencia doméstica en una comunidad chicana de Texas y la cual es comparada literariamente a la mítica figura de La Llorona) como elucidación y punto de partida para una discusión sobre el feminicidio en Latinoamérica, específicamente, en México y en Brasil. Así, la lectura resalta el papel de la telenovela como el

\footnotetext{
${ }^{1}$ Heleno Álvares Bezerra Júnior. Doutor em Literatura Comparada pela Universidade do Estado do Rio de Janeiro. Professor no Mestrado ProfEPT do Instituto Federal do Rio de Janeiro, Campus Mesquita. E-mail: heleno.junior@ifrj.edu.br - https://orcid.org/0000-0003-0275-1994

${ }^{2}$ O conto foi traduzido para o espanhol, não para o português. Por isso, o título em língua portuguesa permanece no original "Woman hollering creek", enquanto a tradução para o espanhol faz jus a tradução da obra como "El arroyo de La Llorona".
}

Texto recebido em 30/12/2019 e aceito para publicação em 09/01/2020. 
elemento mediático propagador de la idealización del amor y de la ilusión de prosperidad en E.E.U.U. (American Dream); valores que, en nombre del amor y de la familia hetero-normativa, relega la mujer a la domesticidad, privándole de actividades intelectuales y apartándole del mercado de trabajo. Por intensificar la mirada feminista sobre las especificidades de la mujer latina, el texto converge tópicos inherentes a la Teoría Poscolonial, y también al Feminismo Poscolonial, en el cual destaca la identidad marginalizada y en tránsito, resistencia cultural e interculturalidad, la intraducibilidad lingüístico-cultural tan como la práctica migratoria relacionada a una mejor calidad de vida. Considerando que la representación de lo inverosímil está también ubicado en la frontera entre el anglicismo y la hispanidad, el texto demostrará como las lecturas relacionadas al Fantástico, al Realismo Mágico y al Gótico Poscolonial enfatizan la adopción del símbolo folclórico de la Llorona en México, como icono de resistencia, la sumisión y del padecimiento sometidos al cuerpo femenino, debido a las estructuras de las sociedades patriarcales de Latinoamérica.

Palabras clave: Feminicidio; Latinoamérica; Identidad en tránsito; Resistencia cultural; Poscolonialismo.

From soap-operas to reality: violence against Latin-American woman in Sandra Cisnero's "Woman hollering creek

\begin{abstract}
In order to illustrate and prompt a discussion on feminicide in Latin America (highlighting Mexico and Brazil), this article makes use of hideous events experienced by the protagonist of "Woman hollering creek"': a Latin American woman, ignorant of English language and victim of domestic violence in a Texan Chicana Community, who is literally compared to the mythic La Llorona. Being so, the text highlights the role of Latin-American soap-operas of disseminating and perpetuating concepts like "idealized love" and prosperity in the USA (American Dream) for the sake of a heteronormative family paradigm. Devoted to the ideal of perfect happy family, the Latin woman is confined to domesticity, being secluded from intellectual enterprises and from participating in the marketplace. By intensifying the feminist perspective on the Latin woman's idiosyncrasies, topics peculiar to the Post-colonial Theory, and Post-colonial Feminism like misplaced and marginal identities, cultural resistance, interculturality, linguistic and cultural untranslatability as well as the diasporic practice for the sake of a better life will be stressed. Likewise, given that uneventful representations of blurred borders between Englishness and Hispanicity are also at stake in the shortstory, this analysis will show how strongly readings about the Fantastic, Magic Realism and Postcolonial Gothicism point to a multicultural portrayal of the Latin-American hollering woman, an icon of resistance, subservience and suffering thanks to Latin American patriarchal structures.
\end{abstract}

Keywords: Feminicide; Latin America; Misplaced identities; Cultural resistance; Post-Colonialism.

\title{
Da telenovela à realidade: violência contra mulher latina em "Woman hollering creek" de Sandra Cisneros
}

$$
\text { O presente artigo objetiva }
$$

pontuar questões de violência contra a

mulher na América Latina, usando,

para tanto, nações como México e

Brasil como referências de análise.O destaque para tais países se dá pelo fato de ser México o país da protagonista aqui analisada. Afinal embora parte da trama se passe nos EUA, a narrativa abre em um vilarejo 
mexicano anônimo, e encerra com a personagem a caminho do mesmo. Além disso, estando nos EUA, a personagem não teve contato com universo anglófono, resistindo até mesmo os hábitos dos chicanos ${ }^{3}$. Daí a ênfase ao México. Quanto ao Brasil, o mesmo foi escolhido por duas razões: é nesse país que a presente discussão está sendo gerada e, infelizmente um lugar em que 0 feminicídio cresce assustadoramente devido à impunidade. Portanto, nada mais pertinente que associar a tropo literário às realidades mexicana e brasileira. E, ao entrelaçar cultura e literatura, recorreremos ao conto "Woman hollering creek" (1992), também traduzido como "El Arroyo de La Llorona" (1996) da escritora chicana Sandra Cisneros, ao abordar experiências de uma personagem mexicana que, ludibriada pelos ideais de amor romântico das telenovelas, deixa sua terra para se casar com um o chicano Juan Pedro, que a leva para morar em sua comunidade ribeirinha em Seguín, Texas, estranhamente

3 Entende-se por chicano(a) o(a) estadunidense filho(a) de hispânico(a)s; sendo hispânico(a) pessoa natural de países latinoamericanos de língua espanhola (CÁLIZMONTORO, 2000, p 3). conhecida como Woman Hollering Creek. Deparando-se coma frustrante realidade mui aquém do American Dream, Cleófilas, a protagonista tornase uma identidade marginal, mesmo habitando um local de hibridismo cultural: espaço fronteiriço entre a hispanidade e o anglicismo. Assim, ela se mantém como uma identidade da diferença, resistindo aos hábitos dos chicanos no Texas. Posto que uma série de questões alegóricas justapõem Cleófilas a La Llorona (ou La Gritona), figura mítica bemconhecida no folclore mexicano, discutiremos uma série de conceitos ligados a questões pós-coloniais e diaspóricas a fim de compreendermos quais os fatores e condições sociais prendem a protagonista a um marido que a agride fisicamente já na lua-demel. Em última instância, o texto retomará aspectos teóricos apresentados nas páginas introdutórias, mostrando o esforço de instituições internacionais para erradicar a cultura do feminicídio, e um descumprimento legislativo internacional no que tange à preservação da integridade física da mulher. 
Notoriamente, a telenovela é uma obra ficcional folhetinesca que, atravessando o século $\mathrm{XX}$, continua firme como programação televisiva latino-americana e euroasiática. Há de se considerar que, no circuito internacional, são famosas novelas brasileiras, mexicanas, argentinas, portuguesas, turcas etc. Embora algumas produções mais recentes no Brasil e Argentina venham rompendo com valores convencionais oriundos de um senso-comum baseado no cristianismo e na construção da tradicional família heterossexual (ALMEIDA, 2007), grosso modo, a trama tradicional que agrada a grande massa no Brasil e no México, por exemplo, é pautada na preservação de um etos cristalizado e já naturalizado na América Latina, presente em valores cristalizados expressos em máximas que apregoam 0 amor vitalício, monogâmico

e heteronormativo: padrão da família tradicional supracitada (CALAZANS, 2003). Espera-se que o amor nestes moldes conduza a mulher a um conto de fadas, caso viva resignada às imposições patriarcais (MARQUES; RIBEIRO, 2014). Afinal, a mocinha é uma senhorita virtuosa, provada pelo mal por permissão de forças divinas, até que vença os desafios e nos lembre de que o bem sem prevalece. Até lá, ela passa por um rio de lágrimas, mantendo-se devota ao amor incondicional ao herói com base na fé: motivação e fórmula infalível para se alcançar uma felicidade no porvir nos braços de homem rico galante, romântico,protetor, porto seguro emocional e financeiro da heroína. E, perseguindo a lógica da recompensa materialista para a 'boa menina', é possível afirmar, segundo Heloísa Almeida (2007), que a telenovela transforma "espectadores em consumidores" (p. 179). Com isso, o herói bem-sucedido não somente vencerá terríveis obstáculos para desposar a donzela amada, mas também a mimará com presentes caríssimos, como prova de um grande amor duradouro e insubstituível. Como se vê no conto, Cleófilas, quando solteira, sonhava com um amor idealizado, cantado em verso e prosa, enfatizado nas telenovelas: "[That] kind of books and songs and telenovelas describe when one finds, finally, the great love of one's life and does whatever once can, must do, at whatever the cost. Tú o Nadie. 'Youor 
No One ${ }^{4 \prime \prime}$ (CISNEROS, 1992, p. 44).

No conto, o amor associado ao consumismo e à aquisição de bens é ainda evidente, quando a protagonista, ao exibir o anel de noivado para amiga,deseja que 0 objeto de ostentação provoque inveja nas jovens do bairro: "Seguín, Tejas. A nice sterlingring to it. The tinkle of Money. She would get to wear outfits like the women on the tele, like Lúcia Méndez. And wouldn't Chela be jealous ${ }^{5 "}$ (CISNEROS, 1992, p. 45). Em outro trecho, o pai de Cleófilas se gaba da posição social de Juan Pedro: "He has a very important position in Seguín with a beer company. Or is it tires?" [...]

\footnotetext{
4 "[Esse] tipo de livros, músicas e novelas descrevem que, quando finalmente se encontra o grande amor da vida, você deve esforçar-se ao máximo e fazer o que estiver ao a seu alcance a qualquer preço. 'Você ou ninguém' - título da atual novela predileta".
}

Devido à constante mistura entre as línguas inglesa e espanhola no conto, as citações serão apresentadas na versão original com tradução para o português em nota de rodapé. Os demais cotejos teóricos em língua estrangeira serão automaticamente vertidos para o português também com tradução de nossa autoria. Todos os grifos em citações ao longo do artigo são originais.

5 "Seguín, Texas. Um belo anel de prata para a ocasião. O tilintar do dinheiro. Ela usaria roupas e adereços como as mulheres da novela, como Lúcia Méndez. E Chela não ficaria enciumada?" [tradução nossa; grifos originais]
So they will get married in spring. [...] Youk now new lyweds. New paint and new furniture. Why not? He can afford it"6 (CISNEROS, 1992, p. 45).

Segundo Janaína Calazans (2003, p. 4), “a incorporação de temas e personagens de contos de fadas em novelas é bastante evidente [...], especialmente pela incorporação de arquétipos e pela seleção de tópicos discursivos semelhantes". Entretanto, o perfil de homem latino-americano é embevecido de masculinidade tóxica, algo inerente ao etos de culturas neolatinas, segundo 0 qual a autoridade patriarcal e misógina legitima a punição do corpo feminino. Daí, a perpetuação de estruturas de poder calçadas em uma cultura de violência doméstica que, com base no controle e penalidade do corpo (FOUCAULT, 1987, p. 43), torna-se responsável pelo alarmante índice de feminicídio. No conto,logo após o casamento, Juan Pedro passa a exibir uma imagem opressora para com a esposa que o descreve da seguinte

${ }^{6}$ Ele tem um cargo muito importante em Seguín em uma empresa de cerveja. Ou seria de pneus? "[...] Então, vão se casar na primavera. [...] Você sabe como são recémcasados. Pintura nova e móveis novos. Por que não? Ele pode bancar tudo isso " 
modo: "this man, this father, this rival, this keeper, this lord, this master, this husband till kingdom come ${ }^{7 \text { ", }}$ (CISNEROS, 1992, p. 49).

Já nas primeiras linhas do conto, a narradora, ironicamente, descreve a cena em que o pai de Cleófilas, tal como um rei, dá a mão da filha em casamento ao superestimado Juan Pedro como se o suposto príncipe encantado fosse arrancar a princesa de terras empoeiradas, conduzindo-a a um reino próspero com estradas pavimentadas: "The day Don Serafin gave Juan Pedro Martinez Sánchez permission to take Cleófilas Enriqueta De León Hernández as his bride [...] several miles of dirt road and several miles of paved [one], over one border and beyond to a town en el otro lado" (CISNEROS, 1992, p. 43). Em outro trecho, Cleófilas também é descrita como uma princesa: "she admitted she had been brought up a

\footnotetext{
7 "esse homem, esse pai, esse inimigo, esse provedor, esse senhor, esse mestre, esse marido até o fim dos tempos.

8 "O dia em que Don Serafin deu a Juan Pedro Martinez Sánchez permissão para tomar Cleófilas Enriqueta De León Hernández como esposa[...] e a fazer atravessar vários quilômetros de estrada de terra e vários quilômetros de asfalto após a fronteira para além de uma cidade do outro lado"
}

little leniently as an only daughter - la consentida, the princess ${ }^{9,}$ (CISNEROS, 1992, p. 47-8). Meses mais tarde, Cleófilas é transportada para uma terra idealizada em um carro moderno, como se, partindo na carruagem da Cinderela, deixasse, para trás, a pobreza: "They will marry in spring when he can take off work, and then they will drive off in his new pick-up, did you see it ${ }^{10}$ ?" (CISNEROS, 1992, p. 45). Mal sabia ela que o sonho de enriquecer nos EUA seria uma cilada que a manteria como 'gata borralheira'.Isso porque, em Seguín, ela sequer teria um aparelho de televisão. O marido-dono não queria que ela tivesse contato com o mundo externo, lançando fora até mesmo os livros de ficção romântica. Assim, o príncipe encantado logo se transformou em sapo: 'Well, he's always been husky, [...] farts and belches and snores as well as laughs and kisses and holds me ${ }^{11 "}$

\footnotetext{
9 "ela admitiu ter sido criada um pouco desregrada como filha única - a mimada, a princesa"

10 "Eles se casarão na primavera, quando ele puder tirar recesso no trabalho, e então viajarão na nova camionete dele, você viu?"

11 "Ele não é muito alto, não se parece com os homens nas novelas. Seu rosto ainda tinha
} 
(CISNEROS, 1992, p. 49). Pior ainda, Juan Pedro não é romântico: "[he] doesn't care at all for music and telenovelas or romance or roses or the moon floating pearly over the arroyo, or by the bedroom window ${ }^{12,}$ (CISNEROS, 1992, p. 49). Com isso, o American Dream e o conto de fadas logo desmoronaram. 0 jornal financeiro Fact Tank, com dados estatísticos de Pew Reserch Center, publicou em 11 de setembro de 2018 que os latinos, principalmente os hispânicos são os que mais acreditam no American Dream (p. 1-2). Em contrapartida, a Gazeta digital publicou,aos 19 de dezembro de 2019, que $50 \%$ das prisões de brasileiros nos Estados Unidos estão associadas à imigração ilegal (p. 1).

Em muitas famílias mexicanas e brasileiras, sobretudo, de classes menos favorecidas, o homem é o provedor e esposa, do lar. E, pela dependência econômica, inúmeras

cicatrizes de acne. Ele tem um pouco de barriga [...]. Bem, sempre foi parrudo. Este homem que peida, arrota e ronca, além de rir, beijar e me abraçar".

12 "[ele] não liga para música e telenovelas, romance ou rosas ou a lua flutuando em tom de pérola sobre o ribeiro, ou pela janela do quarto" mulheres se submetem a maus tratos, especialmente sendo mães. O ideal da telenovela bem como discursos religiosos fazem com que várias dessas mulheres acreditam na transformação de seus respectivos companheiros por intermédio do amor. Em nome da fé, esperam que um milagre divino liberte os homens do instinto violento. Quanto a isso, o Pastor Renato Vargens (2017) admite que, infelizmente, igrejas evangélicas estão repletas de mulheres que apanham dos maridos assim como 90\% de vítimas de violência familiar que recorrem a ONGs são religiosas (p. 1). Com isso,muitas delas se deixam dominar, vindo, às vezes, a óbito, por não prestarem queixa contra os agressores. Em função da impunidade, o problema cresce assustadoramente em países onde práticas misóginas são naturalizadas. No conto, Cleófilas, mesmo chocada, tenta relevar os abusos por dó do marido.Supostamente, seria só uma fase a ser vencida com amor. Até que, com o passar do tempo, a situação agrava-se cada vez mais:

[W]hen it happened the first time, when they were barely man and wife, she had been so stunned, it left her speechless, motionless, numb. She had done nothing but reach up to the 
heat on her mouth and stare at the blood on her hand, as if even then she didn't understand.[...] The first time she had been so surprised she didn't cry out or try to defend herself. She had always said she would strike back if a man, any man, were to strike her. But when the moment came, he slapped her once, and then again, and again; until the lip split and bled an orchid of blood, she didn't fight back, she didn't break into tears, she didn't run away as she imagined she might when she saw such things in the telenovelas [...] She could think of nothing to say, said nothing". Just stroked the dark curls of the man who wept and would weep like a child, his tears of repentance and shame, this time and each $^{13}$ (CISNEROS, 1992, p. 48-9).

Em alusão a este trecho do conto, Rafael Pérez-Torres (2006) afirma que "Cléófilas é convocada a perpetrar o papel de mãe consoladora e perdoadora para o marido" (PÉREZTORRES, 2006, p. 74), já que Juan

13 "[Quando] aconteceu pela primeira vez, quando mal se tornaram marido e mulher, ela ficou tão aturdida que ficou sem fala, imóvel, dormente. Ela não fez nada além de elevar os dedos até o canto quente da boca e encarar o sangue na mão, como se, mesmo assim,não entendesse. [...] $\mathrm{Na}$ primeira vez, ficou tão surpresa que não chorou ou tentou se defender. Ela sempre dizia que revidaria se um homem, qualquer homem, a atacasse. Mas quando chegou o momento, ele lhe deu um tapa uma vez e depois outra e outra vez; até que o lábio se partiu e sangrou uma orquídea de sangue, ela não revidou, não chorou, não fugiu como imaginara, quando vira essas coisas nas novelas [...] Não teve nada a dizer, não disse nada. Apenas acariciou os cachos escuros do homem que chorava e chorava como uma criança, suas lágrimas de arrependimento e vergonha naquela ocasião e em todas as demais"
Pedro revertia a vitimização, comportando-se, nessas horas, como um menino chorão. Com isso, o casamento só piorou: "Cleófilas thought her life would have to be like that, like a telenovela, only now the episodes got sadder and sadder. And there were no commercials in between for comic relief. And no happy ending insight $^{14 "}$ (CISNEROS, 1992, p. 52-53). Essa insistente projeção do cotidiano na telenovela, segundo Samira Campedelli (1985), justifica-se pela "capacidade que a televisão tem de absorver o real” (p.49). Afinal, a ficção televisiva "faz que o telespectador coexista com 0 acontecimento à maneira do sonho" (CAMPEDELLI, 1992, p. 49). Com isso, o que se vê na televisão "tende a ser percebido como real - porque gera formas de expressão que trabalham o sonho, provocando inversão de valores, acentuando outros, deformando ou estabelecendo uma lógica possível na realidade" (CAMPEDELLI, 1992, p. 4950). Para Cleófilas, a projeção da vida real na telenovela só lhe trouxe

14 "Cleófilas imaginou que sua vida teria que ser assim, como uma telenovela, só que agora os episódios ficaram cada vez mais tristes. E não havia comerciais entre eles para alívio cômico. E nenhum final feliz à vista". 
frustrações;transformando-a

paulatinamente em La Llorona, à medida que a violência transborda a questão física, toca em questões emocionais, afetando a autoestima e o senso de dignidade. É, em virtude do desrespeito e rejeição do marido, incompreensão e escárnio da comunidade que a cerca, a personagem é fadada à introspecção, quase em isolamento social.E, aos poucos, assume o papel da figura folclórica que dá nome ao córrego: Woman Hollering Creek, uma tentativa mal sucedida de dizer La Llorona em língua inglesa de importância metaficcional inestimável na narrativa.Quanto ao mito, a própria narrativa explica que o eco sibilante do córrego na casa faz com que Cleófilas se atente para o fato de que $\mathrm{La}$ Llorona a chama para junto de si: "The stream [...], a thing with a voice of its own, all day and all night calling in its high silver voice. Is it La Llorona, the weeping woman [...] who drowned her own chidren? ${ }^{15}$ " (CISNEROS, 1992, p. 51). Por fim, vivendo em um vale de

\footnotetext{
${ }^{15}$ O riacho, [...] uma coisa com voz própria, chamando,o dia todo e a noite inteira, com sua alta voz prateada. É La Llorona, a mulher que chora [...] que afogou seus próprios filhos?"
}

lágrimas entre duas vizinhas cujos nomes Dolores e Soledad tipificam alegoricamente a dor e a solidão, Cleófilas passa a entender epifanicamente que 0 nome do arroio,outrora incompreendido,referese à alma penada que mata os filhos e a si mesma. De acordo com a lenda, La Llorona não era louca ou assassina.Ela foge com os filhos da violência de um marido truculento e, então, quando prestes a ser alcançada pelo algoz na tentativa de fuga, entra em pânico.Tomada por um impulso protetor e irracional, lança os filhos no rio para lhes poupar sofrimento. No âmago do desespero,mostra-se tão arrependida do desatino que, também se joga nas águas, tanto para escapar do feminicídio quanto para se juntar aos filhos. Assim, de acordo com a lenda, o fantasma materno ronda margens de rios, córregos, lagos e lagoas, chorando e gritando, em busca dos infantes jamais reencontrados. Segundo Pérez-Torres:

$\mathrm{Na}$ lenda, La Llorona é a mulher em prantos que afogou seus próprios filhos e agora se lamuria junto aos corpos na água. [...] Neste momento, subitamente percebemos que Cleófilas, ao pensar neste script violento, poderia estar cedendo espaço para o desejo de matar a prole que carrega consigo o nome do marido. Por último, ela se recusa a 
encenar 0 papel de que destrutivamente trai o amor materno. Ao renunciar o papel prescrito segundo a lenda, Cleófilas abre novas searas no âmbito da subjetividade de gênero (PÉREZTORRES, 2006, p. 75).

Tal renúncia ao status de $L a$ Llorona é questionável, pois amar os filhos não a faz deixar de sofrer, muito menos de chorar calada. Por outro lado, a identificação com a figura lendária não afrouxa 0 instinto materno. Além do mais, tornar-se La Llorona pode ser oximoricamente bom e ruim. Afinal, encarnar essa condição de vítima também significa incorporar a figura de uma guerreira.

A dificuldade de convivência com os chicanos afrontosos e desprendimento afetivo em relação ao marido fazem com que Cleófilas resista ao hibridismo cultura entre a hispanidade e o anglicismo, visto que, apesar da prepotência da comunidade local para com ela, não são suficientemente americanizados para a sociedade mainstream nos EUA. Com dificuldade de adaptação, Cleófilas não se adequa aos costumes do vilarejo, visto que as mulheres a tratam como primitiva e incivilizada. Como afirma Homi Bhabha (2010), "O imaginário da distância social [...] dá relevo diferenças sociais, temporais, que interrompem nossa noção conspiratória de contemporaneidade cultural" (p. 23). E, com o estigma de latina rudimentar, a protagonista se fecha ainda mais em seu casulo. Neste conto de Sandra Cisneros, a pré-disposição a não acolher o Outro nos EUA, faz da tradução cultural um ato inatingível para Cleófilas, tornandose, paradoxalmente, marca de Alteridade. Paradoxalmente porque esperamos que a tradução seja um mecanismo transitivo, abrindo possibilidades para que tanto 0 anglicismo e a hispanidade sejam sujeitos em diferentes contextos; entretanto, o que se percebe no texto é uma austera intransitividade nas relações

culturas mexicana/estadunidense regida por uma relação de poder díspar, pesando a favor do universo anglófono. Por fim, se por um lado, o espaço hispânico resiste à cultura hegemônica, por outro lado, o establishment anglicista também declara repúdio aos periféricos marginalizados. Com isso, Cisneros cria uma provocação, visando a...

contestar as reivindicações de supremacia cultural, quer sejam compostas por nações 
metropolitanas pós-imperialistas, quer a favor de novas nações periféricas independentes. $\mathrm{O}$ marginal ou minoria não é espaço de automarginalização celebratória e utópica. É uma intervenção muito mais substancial nas justificativas da modernidade - progresso, homogeneidade, organicismo cultural, o patriotismo exacerbado, o passado distante, que racionalizam as tendências normatizantes e autoritárias em um entrelace de culturas em nome de um interesse nacional ou prerrogativa étnica (BHABHA, 1995, p. 4).

Enquanto identidades em trânsito, os chicanos procuram engajar-se num processo de tradução cultural que, segundo Bhabha, pode ser compreendida da seguinte maneira:

A tradução é a natureza performativa da comunicação cultural. É antes a linguagem in actu (enunciação, posicionalidade) do que a linguagem in situ (énoncé, ou proposicionalidade). E o signo da tradução conta, ou 'canta', continuamente os diferentes tempos e espaços entre a autoridade cultural e suas práticas performativas. O 'tempo' da tradução consiste naquele movimento de significado, o princípio e a prática de uma comunicação que [...] 'põe o original em funcionamento para descanonizá-lo, dando-lhe 0 movimento de fragmentação, um perambular de errância, uma espécie de exílio permanente. [...] A tradução cultural dessacraliza as pressuposições transparentes da supremacia cultural e, nesse próprio ato, exige uma especificidade contextual, uma diferenciação histórica no interior das posições minoritárias" [ênfase original] (BHABHA, 2010, p. 313-4)

O próprio título do conto evidencia a dificuldade da comunidade de Seguín traduzir-se culturalmente por completo. Isso porque os habitantes do vilarejo misturaram sintaxe inglesa com a espanhola ao dar nome ao riacho que banha a aldeia. Por exemplo, no sintagma nominal [woman hollering] ${ }^{\text {APOSTO }}$ DESIGNATIVO [creek] ${ }^{\text {NÚCLEO NOMINAL, se }}$ analisarmos a posição dos elementos internos ao aposto designativo "woman hollering' [mulher chorona] separadamente de 'creek', veremos que os componentes se encontram invertidos em língua inglesa, já que a regra gramatical prevê que a qualificação e a designação antecedem 0 núcleo nominal (substantivo). Por outro lado, o aposto 'woman hollering' está corretamente posicionado em relação a 'creek' 
[riacho]. Com isso, em vez de 'Hollering Woman Creek', o vilarejo passou a se chamar 'Woman Hollering Creek, provavelmente, por ser La Llorona uma expressão culturalmente relevante para os primeiros hispânicos da região que, vivenciando um hibridismo cultural, adotaram vocábulos do inglês, porém mantiveram a sintaxe espanhola em mente. Estranho é que a geração de hoje sequer reconhece que seus antepassados hispânicos/chicanos nomearam o córrego ao misturar inglês e espanhol:

La Gritona. Such a funny name for such a lovely arroyo. But that's what they called the creek that ran behind the house. Though no one could say whether the woman had hollered from anger or pain, [...] a name no one from these parts questioned, little less understood. Pués allá de los indios, quién sabe-whoknows, the towns people shrugged, because it was of no concern to their lives how this trickle of water received its curious name ${ }^{16}$ (CISNEROS, 1992, p. 46)

\footnotetext{
16“"La Gritona. Um nome tão engraçado para um córrego mui adorável. Mas é assim que eles chamavam o riacho que corria atrás da casa. Embora ninguém pudesse dizer se a mulher gritou de raiva ou dor, [...] um nome que ninguém dessas partes questionou, muito menos compreendeu. É de uma época muito antes dos índios, quem sabe, as pessoas da cidade encolhiam os ombros, porque não interessava às suas vidas como esse fio de água recebeu esse curioso nome".
}

É claro que a expressão tem a intenção de ser um trocadilho jocoso em nome do hibridismo cultural; porém, não necessariamente compreensível para falantes de língua inglesa em primeiro instante. Segundo Susan Bassnett (2005), "os trocadilhos [...] só fazem sentido em uma certa cultura" (p. 46); porém, no caso de "Woman hollering creek", o jogo de palavras encontra-se tanto em inglês quanto espanhol, embora por diferentes motivos. Sintaticamente, a brincadeira lexical se dá na língua inglesa, mas, culturalmente, ela acontece em língua espanhola.Aliás, segundo Liliana Valenzuela, tradutora do compêndio Woman hollering creek (1996) para o espanhol, há muitas variáveis na relação inglês-espanhol em cada conto da coletânea. Por isso, decidiu adotar o "Tex-Mex", espanhol falado no Texas, mesmo assim, precisou considerar diferentes níveis de anglicismo e hispanização identificados nas narrativas:

Alguns dos contos usam o inglês formal, outros, os modismos estadunidenses, outros refletem 0 espanhol do interior do México vertido ao inglês, enquanto outros inglês de fronteira generosamente recheado de palavras e expressões em espanhol. [...] A primeira questão que tive de enfrentar ao traduzir era, sim, usar o espanhol padrão, ou o 
castelhano genérico, ou o espanhol mexicano e, mais especificamente, o Tex-Mex, como é afetuosamente conhecido na fronteira. Não foi difícil optar pelo último. E assim o digo mas principalmente porque se passam [majoritariamente] nos EUA (VALENZUELA apud CISNEROS, p. 187-188).

O problema da

interculturalidade é que a suposta hibridização pode se dar a partir de uma relação hegemônica, na qual uma cultura se sobrepõe à outra por questões político-econômicas internacionais. O maior exemplo de hegemonia na interculturalidade é a prepotência do anglicismo para com outras matrizes culturais. Nas palavras de Sherry Simon (1996), a...

crescente voracidade do inglês de assimilar todas as culturas, tornar-se o único veículo de cosmopolitismo, é reconhecida por certos acadêmicos estadunidenses como uma ameaça à diferença cultural [e] o hibridismo, caro aos estudos culturais, uma vez dominado pelo anglicismo, alimenta a devotada tradição monoglota nas políticas de engenharia linguísticas estadunidenses (SIMON, 1996, p. 154).

E é justamente a questão de sentir-se mais 'americanizado' o que justifica o sentimento de superioridade povo de Seguín para com Cleófilas, criando uma tríplice estratificação social; porque, enquanto a sociedade anglófona estadunidense ignora populações linguística e culturalmente periféricas como a comunidade chicana, esta, por sua vez, reproduzindo o modus operandi do opressor, desdenha a mulher mexicana, situada à parte do Englishness, ou seja, processo de assimilação cultural anglicista (SPIVAK, 1988, p. 77).O fato de certas identidades, como Cleófilas, não conseguirem desenvolver formas de negociação cultural com novos língua e etos demarca o que Homi Bhabha denomina como intraduzibilidade cultural:

A cultura migrante do 'entrelugar', a posição minoritária, dramatiza a atividade da intraduzibilidade da cultura; ao fazê-lo, ela desloca a questão da apropriação da cultura para além do sonho do assimilacionista, ou do pesadelo racista, de uma transmissão total do conteúdo (BHABHA, 2010, p. 308).

Assim, a intraduzibilidade gera um entrelugar, uma espécie de fissura em comunidades culturalmente híbrida. Isso porque, se, por um lado, a comunidade chicana, por si só, já é vista como espaço fronteiriço, o latinoamericano nela inserido e uma vez deslocado linguística e culturalmente, passa a ocupar um espaço intersticial de não pertencimento [unbelongingness], vivendo a condição 
BEZERRA JÚNIOR, Heleno Álvares. Da telenovela à realidade: violência contra mulher latina em "Woman hollering creek" de Sandra Cisneros. PragMATIZES - Revista Latino-Americana de Estudos em Cultura, Niterói/RJ, Ano 10, n. 18, p. 34-65, out. 2019 a março 2020.

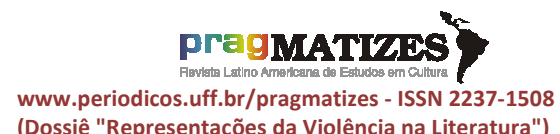

(Dossiê "Representações da Violência na Literatura") de uma identidade situacional que, na impossibilidade de tradução cultural, encontra-se fadada a uma marginalização absoluta, face à inadequação à comunidade culturalmente e um total descompasso para com a sociedade do establishment. Ainda segundo Bhabha,

Esses 'entrelugares' fornecem o terreno para a elaboração de estratégias de subjetivação singular e coletiva - que dão início a novos signos de identidade e postos inovadores de colaboração e contestação, no ato de definir a própria ideia de sociedade. É na abrangência dos interstícios - a sobreposição e o deslocamento de domínios da diferença - que as experiências intersubjetivas [...] são negociad[as] (2010, p. 20)

Mais adiante, o mesmo teórico acrescenta:

É o que deve ser mapeado como um novo espaço internacional de realidades históricas descontínuas é, na verdade, o problema de significar as passagens intersticiais $e$ os processos de diferença cultural que estão escritos no 'entrelugar', na dissolução temporal que 0 texto 'global'. É, ironicamente, o momento ou mesmo movimento desintegrador da enunciação - aquela disjunção repentina no presente - que torna possível a expressão do alcance global da cultura. E, paradoxalmente, é apenas através de uma estrutura de cisão e deslocamento - 'o descentramento fragmentado $e$ esquizofrênico do eu" - que a arquitetura do novo sujeito histórico emerge nos próprios limites da representação, para 'permitir uma representação situacional por parte do indivíduo daquela totalidade mais vista e irrepresentável, que é o conjunto das estruturas da sociedade como um todo (BHAHA, 2010, p. 298).

Cleófilas passa a operar em um espaço intersticial subjacente às fronteiras do hibridismo a que resiste, mostrando se inflexível ao mélange de paradigmas político-linguísticos e socioeconômicos dos limiares geográficos em que se encontra. Mais do que isso, ao se identificar com $L a$ Llorona, ela ativa uma estratégia de subjetivação, constituindo uma 'identidade da diferença'. (DERRIDA, 1995, p. 38). Assim, Cleófilas vivencia a alteridade na alteridade. $E$ por quê?Na condição de La Llonora, tornase o'Outro’, não pertencendo sequer ao espaço de marginalização em que vivem os chicanos em relação aos caucasianos no Texas.Quanto a isso, Homi Bhabha afirma o seguinte:

O que está em questão é a natureza performativa das identidades diferenciais: a regulação e negociação daqueles espaços que estão continuamente, contingencialmente, se abrindo, retraçando as fronteiras, expondo os limites de qualquer alegação de um signo singular ou autônomo de diferença - seja ele classe, gênero ou raça. Tais atribuições de diferenças sociais - onde a diferença não é nem o Um nem o Outro, mas algo além, intervalar - encontram sua agência em uma forma de um futuro em que o passado não é originário, em que o presente não é simplesmente transitório. Trata-se, 
se me permitem levar adiante 0 argumento, de um futuro intersticial, que emerge no entremeio entre as exigências do passado e as necessidades do presente (2010, p. 301).

Avessa à hierarquização de estruturas linguístico-socioculturais, Sherry Simon apresenta, criticamente, o anglicismo como ícone de superioridade ocasionada por valores defendidos pelo Neoimperialismo estadunidense, que estipulam um papel subalterno da mulher do terceiro mundo, uma vez cerceada por paradigmas anglófonos. Tal questão, além de atingir, obviamente, a comunidade chicana, afeta ainda mais o universo latino-americano de Cleófilas. Avessa à questionável supremacia estadunidense, Simon pontua que o julgo de sistemas anglicistas trazem consigo o selo de uma pretensa superioridade (1996, p. 145), gerando o que Thomas Bonnici (1998) denomina de dupla colonização da mulher.

No caso de Cleófilas, por exemplo, a personagem sofre um mecanismo de opressão patriarcal representado pela figura de Juan Pedro e um segundo mecanismo de opressão na comunidade chicana por não estar habituada aos costumes dos
EUA. Assim sendo, para Bonnici, Cleófilas vive uma 'dupla colonização',pressionada por forças do patriarcado e dos reflexos da cultura hegemônica estadunidense nos chicanos; daí a dupla colonização mesmo em tempos pós-coloniais ${ }^{17}$. Nas palavras de Bonnici,

Há uma estreita relação entre os estudos pós-coloniais e o feminismo. Em primeiro lugar, há uma analogia entre patriarcalismo / feminismo e metrópole / colônia ou colonizador / colonizado. 'Uma mulher da colônia é uma metáfora da mulher como colônia' (Du Plessis, 1985). Em segundo lugar, se 0 homem foi colonizado, a mulher, nas sociedades pós-coloniais, foi duplamente colonizada. [...] Portanto, o objetivo dos discursos póscoloniais e do feminismo é a integração da mulher marginalizada à sociedade. De modo semelhante ao que aconteceu nas reflexões do discurso pós-colonial, no primeiro

${ }^{17}$ Entende-se como Teoria Pós-colonial a área de Estudos Culturais que procura entender os graus de dependência ou independência culturais e financeiros das antigas colônias inglesas, marcado pelo fim da era colonial britânica em 1957, marcada pela independência da Índia. Nesse sentido, o termo pós-colonial, em primeira instância, não diz respeito às colonizações espanholas, portuguesas, francesas etc., porém, como as questões teóricas se aplicam a outras realidades, o Pós-Colonialismo ganhou lastro mundial. Ocorre que enquanto o Imperialismo Britânico se enfraquecia, surgia uma outra forma de imperialismo neocolonial, neoliberal marcado pelo processo de Globalização liderado pelos EUA. Por isso, ao se referir à questão patriarcal e à dominação cultural da Globalização, Bonnici adota o termo dupla colonização, referindo-se à herança do patriarcado e dominações culturais tanto eurocêntrica quanto estadunidense. 
período do discurso feminista, a preocupação consistia na substituição das estruturas de dominação. [...] Nestes debates, o feminismo trouxe à luz muitas questões que o pós-colonialismo havia deixado obscuras; outrossim, o pós-colonialismo ajudou o feminismo a precaver-se de pressupostos ocidentais do discurso feminista (BONNICl, 1998, p. 13)

O feminismo pós-colonial nos ajuda a perceber que, em âmbito internacional, casos de feminicídio são mais recorrentes em países de terceiro mundo. Não porque os países mais sejam incivilizados, mas porque a pressão internacional para a resolução de casos de violência contra mulheres, negros e LGBTs é menor. Essa lógica perversa sorrateiramente diminui a dignidade do subalterno, como se a mulher latino-americana, por exemplo, valesse menos que mulheres do primeiro mundo. Além da questão racista subjacente, entra a questão do sentimento de superioridade econômica. A própria comunidade chicana, sentindo-se estadunidense, não se importa com o sofrimento e o silenciamento de Cleófilas, pois, além de mulher, é latino-americana, portanto, inferior aos olhos dos que a cercam, inclusive, na visão do marido.Com isso, estabelece-se a dupla colonização, nos termos de
Bonnici. Este aspecto do conto aponta para o fato de que a mulher mexicana, brasileira, por exemplo, sofre um processo de desumanização no estrangeiro. Pior ainda é pensar que, mesmo em terra natal, esta mulher, muitas vezes, hipersexualizada, é usada como corpo desfrutável, porém indigna de respeito. $\mathrm{Na}$ América Latina, muitos homens espancam e matam a mãe de seus filhos. Em caso de traição conjugal, o homem sente-se no direito de fazê-lo, julgando-se procriador por natureza, contudo, historicamente, a mulher latinoamericana é assassinada por não se manter casta.Em outros casos, são mortas por desafiar os paradigmas patriarcais. De volta ao universo ficcional de Cisneros, vale ressaltar que várias narrativas da autora mostram a força da cultura de feminicídio em comunidades chicanas, como extensão das práticas latinoamericanas. Nos contos e romances da autora, os algozes se mantêm na impunidade graças a uma dinâmica operacionalde descumprimentos legais protecionista de patriarcados. Com isso, a impenitência se dá tanto em espaços latino-americanos, como Brasil e México quanto comunidades 
chicanas, geralmente concentradas no

Texas, Califórnia, Flórida e Chicago.

Em "Woman hollering creek", à medida que Cleófilas toma consciência de que ninguém a respeita em Seguín, exceto Dolores e Soledad), tal como La Llorona intenta secretamente fugir daquele espaço de opressão.Porém, com uma criança pequena, grávida de um segundo bebê, desamparada em uma terra remota, dependendo do marido para sobreviver,ela não vê uma solução para aquele tormento e,sem apoio, perde sua voz. Até porque, em Seguín, "a ordem patriarcal não se manifesta como condição ideológica, mas se faz fisicamente presente por meio da própria dinâmica de uma nova cidade estranha" (PÉREZ-TORRES, 2006, p. 75). E por que estranha? De acordo com a protagonista, o vilarejo foi construído distante de tudo para os maridos isolarem as mulheres do resto do mundo, sustentando a cultura do feminicídio: "the townshere are built so that you have to depend on your husbands $^{18 "}$ (CISNEROS, 1992, p. 5051). Em outro trecho, afirma o mesmo crítico que as "restrições econômicas e

\footnotetext{
18 "As cidades daqui são construídas para que vocês tenham que depender dos seus maridos"
}

de gênero que lhe amarram a vida são reforçadas pela geografia da cidade cuja atividade social revolve em torno de troca de bens e não de interação humana. (PÉREZ-TORRES, 2006, p. 75).

Contra o silenciamento do sujeito em estruturas de opressão, Gayatri Spivak (1988) lança a seguinte pergunta, indo de encontro ao 'outro', ao não pertencente, ao sujeito feminino sob a dupla colonização: “pode o subalterno falar?"(p. 78) Pode Cleófilas lutar contra o espancamento? Pode ela escapar do feminicídio? Será - silenciamento uma condição inevitável para a doméstica latinoamericana,

financeiramente dependente do marido, preocupada com a provisão dos filhos e inibida por um sistema neoimperialista cujas condições de trabalho a mantêm calada, principalmente por desqualificação profissional ou por não falar inglês? É fundamental considerar que, além da agressão física contra a mulher, a violência de ordem política e socioeconômica é tão desrespeitosa quanto o espancamento, à medida que o sistema maltrata, aniquila e arranca o senso de autoestima e dignidade do sujeito. Como assevera Spivak, 
"devido à violência de uma inscrição disciplinar social, epistêmica e imperialista em um projeto conhecido em termos essencialistas, a agressão ao outro flui em uma radical prática textual de diferenças" (SPIVAK, 1988, p. 80). De acordo com Minh-Ha (1997),

No contexto da fala das mulheres, o silêncio tem muitas faces. Tal como o véu das mulheres, só pode ser subversivo quando se liberta de um contexto de ausência, falta e medo voltado para o masculino tanto quanto territórios femininos. Por um lado, encaramos 0 perigo de inscrevermos a feminilidade como ausência, como falta e como lacuna ao rejeitar a importância do ato de enunciação. Por outro lado, compreendemos a necessidade de posicionar as mulheres no lado da negatividade e trabalharmos com nuances sutis, por exemplo, em nossa tentativa de subverter sistemas de valores patriarcais. $O$ silêncio como um desejo a não ser dito ou um desejo a ser desdito e tal como uma língua autônoma muito mal-explorada (MINH-HA, 1997, p. 416).

Se, por um lado, ser La Llorona significa incorporar a condição de invisibilidade social de um fantasma; por outro lado, tornar-se simbolicamente perigosa e atuar em silêncio também pode configurar uma estratégia de subversão à dupla colonização. Pegando o gancho da cultura híbrida, a possibilidade de diferentes tratamentos literários aplicáveis à manifestação do inverossímil no conto apontam para o fato de que La Llorona, enquanto representação folclórica,constitui, por si só, um corpus de análise culturalmente híbrido. E por quê? Embora 0 mito possua origem hispânica, suplanta as fronteiras nacionais que oficialmente dividem os limites entre o espanhol e o inglês. Tanto que, na narrativa em análise,o córrego texano (de fato, existente no mundo real) chama-se Woman Hollering Creek em decorrência hibridismo cultural presente em Seguín. Transcendendo a questão toponímica já discutida, La Llorona, na obra de Sandra Cisneros, figura como um objeto de análise que mescla tradições literárias de línguas espanhola e inglesa com tamanha complexidade, pois permite detectarmos uma possível superposição do Fantástico, do Realismo Mágico e do Gótico Póscolonial no tratamento da inverossimilhança no texto, embora tais conceitos possam ser problematizados de maneira autônoma e autoexcludente.

Sabe-se que o Fantástico teoricamente discutido por Tzvetan Todorov (1975), possui grande 
expressividade no universo literário hispânico, principalmente pelo fato de o mestre do Fantástico Gabriel José Garcia Marquez ser mexicano. Para Todorov, o confronto entre a representação mimética da realidade com a manifestação do inverossímil constitui a base teórica para estudos sobre tal subgênero literário. Segundo Todorov, no texto fantástico, apresenta-se "um fenômeno estranho que se pode explicar de duas maneiras, por meio de causas de tipo natural e sobrenatural. A possibilidade de se hesitar entre os dois criou 0 efeito fantástico." (TODOROV, 1975, p. 31). No conto de Cisneros, a sugestão de que o fantasma chama Cleófilas por meio do murmúrio das águas pode ser lido como um traço do fantástico na narrativa pois desafia a lógica. Para além do Fantástico, é possível perceber outro subgênero literário, desta vez, presente tanto em obras literárias hispânicas quanto anglófonas: o Realismo Mágico. Segundo Bill Ashcroft et alii (1998), o universo caribenho, impregnado de mesclagens culturais anglófonas, francófonas e hispânicas cria o Realismo Mágico como um tipo de abordagem folclórica, especificamente voltada para a representação da resistência política do colonizado contra o colonizador.Portanto, pensar La Llorona como a mulher que assombra o sistema patriarcal e a prepotência estadunidense é potencialmente subversivo. Afinal, como explicam Ashcroft et alii (1988, p. 132-133),

voltadas para a realidade peculiar do colonizado, tradições míticas e mágicas eram a característica distintiva de culturas locais e nacionais [no Caribe], [sendo] as formas coletivas pelas quais 0 colonizado expressava sua identidade e articulava sua diferença para com dominantes opressores raciais e coloniais.

Ainda segundo Homi Bhabha, "o Realismo Mágico, após a grande explosão latino-americana, torna-se a linguagem literária do mundo póscolonial emergente. Em meio a estas imagens exorbitantes da naçãoespaço em sua dimensão transnacional" (BHABHA, 1995, p. 7). Intensificando ainda mais esta relação crescente entre a representação política do inverossímil, falemos sobre o Gótico Pós-colonial. Multifacetada, e apresentando variantes bem expressivas desde o século XVIII, a tradição gótica, marca preponderante das literaturas anglófonas, vem 
BEZERRA JÚNIOR, Heleno Álvares. Da telenovela à realidade: violência contra mulher latina em "Woman hollering creek" de Sandra Cisneros. PragMATIZES - Revista Latino-Americana de Estudos em Cultura, Niterói/RJ, Ano 10, n. 18, p. 34-65, out. 2019 a março 2020.

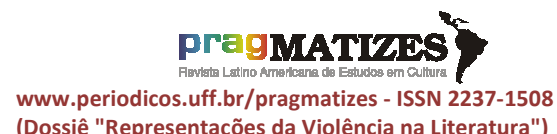

(Dossiê "Representações da Violência na Literatura") passando a representar a colonização britânica e suas consequências no pós-colonial como um espectro que psicanaliticamente assombra o sujeito colonizado desde o segundo meado do século XX.Com escopo maior, o Gótico Pós-colonial engloba 0 Realismo Mágico em narrativas de língua inglesa, justamente por abraçar temáticas mais recentes, como questões diaspóricas, a pobreza, miséria de povos cultural e economicamente de países anglófonos como EUA, Canadá e o Reino Unido, sem, contudo, desprezar as questões coloniais. Nas palavras de Julie $\mathrm{H}$. Azzam (2007),

A ficção gótica pós-colonial surge em resposta a certas condições sociais, históricas ou políticas. A ficção póscolonial adapta uma forma narrativa britânica altamente sintonizada com a distinção e colapso entre o lar e não o lar, o familiar e o estrangeiro. O surgimento do gótico na ficção pós-colonial parece uma resposta ao fracasso da política nacional dividida pelas divisões sectária, de gênero, de classe e de casta. O gótico póscolonial é uma maneira pela qual a literatura pode responder às crescentes questões problemáticas do "terreno doméstico pós-colonial": questões relativas a origens legítimas; habitantes legítimos; usurpação e ocupação; e a nostalgia por uma política nacionalista impossível são entendidas no gótico pós-colonial como perguntas nacionais que são feitas no cotidiano doméstico. [...] Em segundo lugar, o gótico pós-colonial está interessado na representação do estranhamento do lar, tanto como moradia quanto como nação. Se o colonialismo criou um espaço "lar longe de casa" e metaforizou essa divisão espacial da psicanálise através do relacionamento do familiar com o não familiar, então parte da agenda do gótico pós-colonial está revelando que, por trás da construção de uma idealização do lar, existe algo fundamentalmente desagradável. Em terceiro plano, o gótico pós-colonial emprega uma sensibilidade histórica gótica, ou um senso de 'passadismo' no presente. Quarto, se o gótico é o modo narrativo pelo qual a GrãBretanha se assustou com a degeneração cultural, a perda de pureza racial ou cultural, o outro racial, a subversão sexual e a ameaça de que a usurpação e a violência da era colonial possam um dia "retornar". O gótico pós-colonial emprega o gótico como um modo de se assustar com imagens de mulheres transgressoras que ameaçam expor o ventre sombrio de seus próprios contextos históricos e políticos (AZZAM, 2007, p. 1-2).

E é justamente a imagem de uma mulher assustadora, resistente a culturas de colonização que Sandra Cisneros evoca ambiguamente em "Woman hollering creek"; pois, se por um lado, La Llorona, originalmente,constitui um símbolo de rebeldia ao controle patriarcal,por outro lado, ela representa as inúmeras vítimas ceifadas pelo feminicídio na América Latina. Para além disso, uma vez situada nos EUA, La Llorona se mostra marginalizado, porém, enquanto não pertencente e identidade da diferença, figura como símbolo 
resistência às práticas de dominação culturais e socioeconômicas estadunidenses. Daí, a ambivalência da representação folclórica: La Llorona é a mulher que retorna para se vingar da cultura de feminicídio, voltar para assombrar os homens. Ela é a representação do subalterno, gritando e chorando contra a violência doméstica desencadeada por mecanismos de opressão social.

Voltando ao impasse de Cleófilas, em meio a tanto dissabor, de repente, surge um facho de esperança para a protagonista. Prestes a ser mãe segunda vez, ela convence o marido a deixá-la ter uma consulta média e levar o filho Juan Pedrito consigo. A partir daí, ela se depara com outras duas figuras alegóricas. Primeiro, com a médica Graciela (símbolo da graça, riso), depois, Felice (representação da felicidade). No consultório de Graciela, Cleófilas descobre que outras mexicanas iludidas são levadas para Seguín para se tornarem escravas domésticas. Ao mesmo tempo, descobre que a médica está pronta a ajudá-la a regressar à família no México. Enquanto Graciela conversa com Felice ao telefone, ouvimos o seguinte: "Felice! This poor lady's got black-and-blue marks all over. I'm not kidding! [...] Another one of those brides from across the border. And her family's all in Mexico. [...] This lady doesn't even speak English. She hasn't been allowed to call home or write or nothing ${ }^{19 ",}$ (CISNEROS, 1992, p. 51). E para convencer Felice a transportar mãe e filhos até a longínqua estação de ônibus, Graciela acrescenta: "If we don't help her, who will? l'd drive her myself, but she needs to be on that bus before her husband gets home from work ${ }^{20}$, (CISNEROS, 1992, p. 51). Compadecidas, as figuras simbólicas que substituem a dor e a solidão se esforçam para ajudar mãe e filhos, já que Cleófilas espera ser bem-recebida pelo pai. Cleófilas se surpreende com a autonomia financeira das duas mulheres. Principalmente Felice chama a atenção por ter seu próprio carro e dirigir a própria vida. Deste

19 "Felice! Esta pobre senhora tem placas pretas e roxeadas por todo o lado. Não estou brincando [...] Outra daquelas noivas do outro lado da fronteira. E a família dela está no México. [...] essa moça nem fala inglês. Ela não tem permissão para ligar para casa ou escrever ou nada".

20“Se não a ajudarmos, quem a ajudará? Eu a levaria de carro, mas ela precisa estar naquele ônibus antes que o marido chegue em casa do trabalho." 
modo, Cleófilas passa a conhecer um novo perfil de mulheres empoderadas. Conforme afirma Pérez-Torres,

Graciela e Felice substituem o sofrimento romantizado e centrado no masculino, uma vez abraçado pelas vizinhas de Cleófilas, por autonomia feminina e autorrealização. Felice encarna o self relacional cuja única autossuficiência, materializada em sua camionete, beneficia a comunidade feminina de forma mais ampla. Felice serve para encarnar a ação coletiva de mulheres à medida que Graciela e ela se esforçam para libertar Cleófilas da violência doméstica" (PÉREZ-TORRES, 2006, p. 76).

Assim, as novas amigas, em nome da sororidade, providenciam o escape para Cleófilas. Financeiramente independentes, Felice e Graciela investem na conscientização e ajuda a mulheres necessitadas. Afinal, mesmo grávida, Cleófilas chega ao consultório com hematomas. Como expõe Bell Hooks (1997), "não pode haver movimento feminista de massa para dar fim à opressão sexista sem uma frente unida - as mulheres devem tomar iniciativa e demonstrar o poder da solidariedade" (p. 396). Ainda nas palavras de Pérez-Torres, onde não havia esperança, "surge a intervenção de mulheres trabalhando em prol da solidariedade a fim de romper com 0 isolamento e capacitá-la [Cleófilas] e articular seu próprio senso de subjetividade empoderada" (2006, p. 76). Assim, Cleófilas passa a entrar em contato com a agência feminista e uma rede de apoio de e para mulheres. Desse modo, Cleófilas, encantada com a camionete de Felice, admira-se com as altas gargalhadas da motorista, que, ao atravessar a ponte acima do riacho de La Llorona, faz questão de rir bem alto para mostrar que não chora e, enquanto mulher, é muito feliz:

Felice, uma chicana politicamente
ativa que, ao desafiar rótulos de
heterossexualidade
homossexualidade, apregoa,em alta
voz, sua política feminista, aposta na
possibilidade de Cleófilas
compartilhar novas ideias com suas
'compañeras' com narrativas de
pranto no México, novas lendas com
o poder de transformar a temática do
lamento da velha Llorona em outras
tramas predominantemente
misóginas (p. 123 apud PÉREZ-
TORRES, 2006, p. 77).

Mantendo 0 tom otimista, Jacqueline Doyle (1996) espera que Cleófilas seja um agente de transformação social no local de origem. $\mathrm{Na}$ esperança de que a protagonista de Cisneros ganhe visibilidade, Doyle defende a agência da personagem da seguinte forma: "De volta ao lar com seus filhos, pais e 
irmãos, Cleófilas supera a tradição do silêncio e advoga seu direito de falar" (p. 64 apud PÉREZ-TORRES, 2006, p. 77). Clarividentemente, o conto pauta a questão da sororidade e empoderamento feminino: exemplos feministas a serem seguidos. Porém, será que um breve contato com mulheres empoderadas chegou a transformar a protagonista? E quanto ao pai? Como a recepcionará? da mesma forma que o marido não cumpriu as promessas, será que o pai manterá a seguinte promessa? - "I am your father. I will never abandon you ${ }^{21 "}$ (CISNEROS, 1992, p. 43). Independente de qual seja a reação do pai, com medo de morrer nas mãos do marido, Cleófilas se fia na seguinte hipótese: "when a man and a woman love each other, sometimes that loves ours. But a parent's love for a child, a child's for its parents is another thing entirely $^{22 " ~(C I S N E R O S, ~ 1992, ~ p . ~ 43) . ~}$ Fato é que muitos pais em comunidades patriarcais conservadoras latino-americanas não

\footnotetext{
21 "Sou seu pai. Nunca a abandonarei".

22 "quando um homem e uma mulher se amam, às vezes esse amor azeda. Mas 0 amor de um pai por um filho, um filho por seus pais, é completamente diferente"
}

aceitam que as filhas fujam da casa do marido, muito menos com filhos nos braços. Culpam a mulher pelo fracasso do casamento, e entendem o retorno da filha como desonra para o nome do pai.Em função disso, dão peso maior à opinião pública e menor atenção à família. $\mathrm{Na}$ verdade, Cleófilas considerou voltar ao México assim que o sonho de viver um conto de fadas estadunidense esmoreceu, mas não teve coragem em função dos rumores do vilarejo onde se criou: "sometimes she thinks of her father's house. But how could she go back there? What a disgrace. What would the neighbors say? Coming home like that with one baby on her hip and one in the oven. Where's your husband? ${ }^{23}$ (CISNEROS, p. 50). Com base neste raciocínio, Pérez-Torres nos lembra que 0 universo da família de Cleófilas não é "um mundo moldado pela companhia feminina e dificilmente uma comunidade promissora para empoderamento pessoal. Se 0 passado em casa é algum tipo de indício, o retorno de Cleófilas ao

23 "às vezes ela pensa na casa de seu pai. Mas como ela poderia voltar para lá? Que desonra. $\mathrm{O}$ que os vizinhos diriam? Voltando para casa assim com um bebê no quadril e outro no forno. Onde está seu marido?" 
México será indubitavelmente árduo" (PÉREZ-TORRES, 2006, p. 78). Assim sendo, até que ponto os seis irmãos, descritos como 'desastrados' (CISNEROS, 1992, p. 45), apoiariam Cleófilas? Ela retornaria para ser a escrava doméstica de todos os demais, mantendo a posição inicial de gata borralheira? Caso sim, ao menos na antiga casa teria uma televisão para assistir. Posto que o conto termina em aberto, assim como existem deixas de que a heroína consiga ser feliz longe do esposo, há também indícios de que ela possa permanecer como La Llorona. Consideremos que o filho mais velho seja um prenúncio simbólico da permanência do patriarcado. Afinal, ele, além de ser semente do pai, tem o mesmo nome do progenitor. Para Pérez-Torres, "o nome do filho sugere que 0 padrão de violência que Cleófilas suporta não é somente aquele que Juan Pedro repete, mas um padrão que será passado de geração em geração dali por diante" (2006, p. 75).

$E$ quanto às mulheres da desconhecida vila mexicana? Elas ajudarão a filha pródiga? Tudo indica que não, porque, no texto literário, o anônimo vilarejo mexicano é descrito como "The town of gossips. The town of dust and despair"24 (CISNEROS, 1992, p. 50). Ao que tudo indica,a comunidade a quem Cleófilas outrora causou inveja poderá provocar uma retaliação. Afinal, as mulheres daquela vila mexicana foram criadas para fazer cumprir o ideal de amor prescrito nas telenovelas, mantendo-se vítimas em potencial de uma cultura de feminicídio. Por um lado, existe chance de Cleófilas, uma vez defensora da agência feminista, cooptar adeptas para desafiar o sistema patriarcal, porém, as moradoras da antiga vila também podem se acomodar, temendo uma virulenta vingança dos respectivos maridos. Obviamente, a gargalhada de Felice pode tipificar a chegada da felicidade para a protagonista, mas, de igual modo, pode somente demarcar a saída de Seguín. Nos EUA, para vencer o patriarcado, a protagonista contou com o auxílio de mulheres politizadas e financeiramente estáveis. Será que Cleófilas encontrará apoio idêntico no México? Teria ela condições de ser

\footnotetext{
24 "A cidade de fofocas. A cidade de poeira e desespero"
} 
uma multiplicadora de uma agência feminista sem uma rede de sororidade? Independentemente do que posteriormente ocorra, decide voltar à casa paterna em vez de aventurar-se em outro local.Fiada na promessa paterna, ela retornará a uma antiga estrutura patriarcal, talvez pela segurança dos filhos. Ao que tudo indica, a protagonista ignora a questão da pobreza e passa a vislumbrar para o México com nostalgia, encanto e admiração; mas, até que ponto não está criando uma sublimação, remanejando a idealização de um casamento nos moldes do American Dream para uma segunda projeção, agora na forma de 'lar acolhedor'? Segundo Salmon Rushdie (1991), o sujeito diaspórico idealiza a terra natal, embora a sensação de retorno ao lugar de origem não passe de um mito e constitua uma cilada:

pode ser que [...] emigrantes ou expatriados, sejam assombrados por uma sensação de perda, de um desejo urgente por reparação, de olhar para trás, mesmo com o risco de se tornarem estátuas de sal, porque, se, de fato, retrocedermos, também podemos fazê-lo em termos de conhecimento, o que faz emergir profundas incertezas de que nosso distanciamento físico [...] significa, quase inevitavelmente, que não seremos capazes de reivindicar precisamente aquilo que se perdeu; que, em suma, criaremos ficções, não cidades ou vilas de verdade, mas lugares imaginários, terras natais imaginárias" (RUSHDIE, 1991, p. 10).

Ora, se voltar a um lugar conservador em nome de um sonho de regresso ao ninho pode não ser uma decisão segura,retornar ao vilarejo pode tanto ser um ato transgressor para disseminação de valores feministas quanto uma grande armadilha para a filha pródiga do ponto de vista ideológico, visto que a probabilidade de rejeição ao novo no espaço antigo é, infelizmente, maior que a prospecção de transformação de um local onde o apogeu do patriarcado mantém-se estabelecido com mão de ferro há séculos. Afinal, uma família que abre mão de conviver com a filha/irmã para entregá-la a um estranho pode não a receber de bom grado. Sobretudo, agora, sendo já mãe de dois meninos.Considerando que,segundo Rushdie, a projeção do lar é algo potencialmente traiçoeiro, talvez Cleófilas tenha se voltado para lembranças felizes, desconhecendo que a memória, segundo Jacques Le Goff (2010), nada mais é senão a reminiscência do esquecimento.Conforme afirma Le Goff, "nas manipulações conscientes 
ou inconscientes, 0 interesse, a afetividade, o desejo, a inibição, a censura exercem [grande influência] sobre a memória individual (LE GOFF, 2010, p. 422). O caráter seletivo da memória pode pontuar o que é emocionalmente conveniente ao sujeito em momentos de dor, abandono, desatino etc. Daí o perigo da memória pessoal, posto que a perspectiva mnemônica do sujeito se constrói na leitura de cenas pretéritas que 0 mesmo inconscientemente decide recobrar. Como já dito, redirecionar a projeção do conto de fadas na telenovela para sonhar com o retorno ao lar pode ser a repetição de um padrão, um modus operandi que a mantém incapaz de enxergar os perigos da vida. Se assim 0 for, Cleófilas perpetuará 0 status de hollering woman. $\mathrm{E}$, se assim o for, ou fantasma da poderá assombrá-la no local de origem, uma terra onde a prática do feminicídio é ainda uma constante ou ela poderá assumir a figura de La Llorona enquanto guerreira. Daí a forte insistência de que Cleófilas, mesmo sem assassinar os filhos,poderá encarnar a mítica figura da Chorona em todo seu potencial gótico. Enfim,o conto nos faz refletir sobre a realidade de milhares de mulheres latino-americanas e sua condição subserviente diante de estruturas patriarcais avassaladoras. Falar sobre a cultura de feminicídio, o que, infelizmente, ainda é uma necessidade cabal nos dias de hoje, em virtude do que mostram os dados estatísticos de violência contra a mulher na América Latina. Apesar disso, em virtude da repercussão da Declaração Universal dos Direitos Humanos $^{25}$ (1948), seus impactos posteriores e, sobretudo, os crescentes manifestos feministas entre as décadas de 1960 e 1970, a ONU e outras instituições internacionais mais jovens se mobilizaram para lutar contra a violência à mulher latinoamericana.

No tocante à América Latina, instituições contra a violência da mulher têm se estabelecido com o objetivo de promover justiça e proteção judicial. Podemos destacar, por exemplo, a Convenção Americana de Direitos Humanos como ponto de partida, assinada em San José, Costa Rica, 1969, e em vigor em 1978

\footnotetext{
${ }^{25}$ Disponível em https://nacoesunidas.org/wpcontent/uploads/2018/10/DUDH.pdf
} 
(SOUZA, 2013, p. 2).Em seguida, criou-se o Ano Internacional da Mulher em 1975. Quatro anos mais tarde, a ONU promoveu a "Convenção da Mulher em Nova Iorque" (SOUZA, 2013, p. 3).Outra importante conquista foi a criação do Comitê LatinoAmericano para a Defesa dos Direitos da Mulher (CLADEM) em 1987, também em São José, Costa Rica. O comitê hoje tem sede em 13 países, dentre eles, o Brasil. Já em 1994, a iniciativa de implementação de serviços de atendimentos especializados a vítimas de violência se deu em Belém do Pará na "Convenção Interamericana para Prevenir, Punir e Erradicar a Violência contra a Mulher". Na ocasião, países que se responsabilizaram por mudanças legislativas foram Argentina, Bolívia, Brasil Chile, Colômbia, Costa Rica, El Salvador, Guatemala, Honduras, México, Nicarágua, Panamá, Paraguai, Peru, Porto Rico, Uruguai e Venezuela. Também por iniciativa da ONU, em 2010, criou-se, em Nova lorque, o Fundo de Desenvolvimento das Nações Unidas para a Mulher (UNIFEM), a Divisão para o Avanço das Mulheres (DAW), o Escritório de
Assessoria Especial em Questões de Gênero bem como 0 Instituto Internacional de Treinamento e Pesquisa para a Promoção da Mulher (INSTRAW). Por meio da UNIFEM, finalmente foi assegurado o direito à igualdade de gênero entre homens e mulheres. Em 2011, organizou-se a Comissão do Status da Mulher com a finalidade de implementar questões pertinentes à igualdade entre gêneros em questões de educação, desenvolvimento e tecnologia. Um ano depois, comemoraram-se 25 anos de atuação do CLADEM (SOUZA, 2013, p. 5). Em 2018, o mesmo comitê organizou o Foro Social Mundial em Salvador,Brasil ${ }^{26}$. Já no ano seguinte, ocorreu a Conferência Internacional do Status da Mulher, Nova lorque ${ }^{27}$. Assim, percebemos o interesse e engajamento de diferentes instituições na luta contra a misoginia e suas devastadoras consequências.

Como destacamos o México, por ser o país de origem de Cleófilas, e o Brasil, país em que vivemos,

\footnotetext{
${ }^{26}$ Disponível em

https://cladem.org/eventos/foro-social-mundial2018/

${ }^{27}$ Disponível em

https://www.unwomen.org/en/csw/csw63-2019
} 
apresentaremos um breve panorama das realidades legislativas de ambas as nações. No que tange à legislação do México, ressaltamos a criação da "Ley General de Acesso de las Mujeres a Una Vida Libre de Violencia”, promulgada em 2007. Lei esta que vem sofrendo alterações textuais desde então a fim de diminuir brechas interpretativas e, assim, punir agressores de mulheres. $\mathrm{O}$ trecho aqui apresentado sofreu modificações estruturais, tendo sua última revisão em 2018. Lei esta que pretende...

estabelecer uma coordenação entre a Federação, os estados, o Distrito Federal e os municípios para prevenir, punir e erradicar a violência contra as mulheres, bem como os princípios e modalidades para garantir seu acesso a uma vida livre de violência que favorece o seu desenvolvimento e bem-estar, de acordo com os princípios da igualdade e da não discriminação, bem como garantir a democracia, um desenvolvimento integral e sustentável que fortaleça a soberania e 0 regime democrático estabelecidos na Constituição Política dos Estados Unidos Mexicanos (MÉXICO, 2007, p. 1)

Contudo, aos 20 de agosto de 2019, o G1, Jornal online brasileiro noticiou que

entre 2015 a junho de 2019 foram cometidos no México ao menos 3.080 feminicídios. Segundo dados oficiais do governo mexicano, o índice de feminicídio por cada 100 mil mulheres em 2015 era de $0,66 \%$; e em 2018, 1,19\%. Isso significa que,em três anos, os números quase dobraram" (p. 6).

Consta ainda na matéria do mesmo periódico que, a cada 6 horas, mulheres são assassinadas por conhecidos no México (G1, 2019, p. 3)

Foi ainda noticiado que policiais estupraram, em agosto de 2019, a jovem Yolanda, causando comoção e gerando protestos naquele país (G1, 2019, p. 3). Além do mais,

Nos primeiros 181 dias de 2019, foram apresentadas 25,277 queixas, ou seja, 139.6denúncias por dia, 5.8 por hora. Segundo o Instituto Nacional de Estatística e Geografia do México, $75 \%$ dos delitos de abuso sexual são contra mulheres, assim como $80 \%$ dos estupros simples e $88 \%$ dos estupros com agravantes (G1, 2019, p. 5).

\section{Considerando a legislação}

brasileira, temos a Lei no 11.340 /2006, popularmente conhecida como a Lei Maria da Penha, em homenagem à Srạ. $M^{a}$ da Penha Maia Fernandes.Tendo sobrevivido a duas tentativas de homicídio do próprio marido,Fernandes possui sequelas no corpo que a transformaram em uma pessoa paraplégica. De tamanha gravidade, o 'Caso Maria da Penha' foi o primeiro a ser registrado como violência doméstica na Comissão Interamericana dos Direitos Humanos da Organização dos Estados 
Americanos (OEA). Hoje ativista, palestrante, Fernandes também é Coordenadora de Estudos, Pesquisas e Publicações da Associação de Parentes e Amigos de Vítimas de Violência (APAVV) no Ceará28. Idêntico ao texto do México, o Brasil tem, em sua legislação palavraschave, lançando o compromisso com a Convenção Interamericana e com a Declaração dos Direitos Humanos da ONU. Conforme se lê no Artigo 1 da Lei em voga,

Esta Lei cria mecanismos para coibir
e prevenir a violência doméstica e
familiar contra a mulher, nos termos
do $\S 8^{\circ}$ do art. 226 da Constituição
Federal, da Convenção sobre a
Eliminação de Todas as Formas de
Violência contra a Mulher, da
Convenção Interamericana para
Prevenir, Punir e Erradicar a
Violência contra a Mulher e de outros
tratados internacionais ratificados
pela República Federativa do Brasil;
dispõe sobre a criação dos Juizados
de Violência Doméstica e Familiar
contra a Mulher; e estabelece
medidas de assistência e proteção
às mulheres em situação de
violência doméstica
familiar(BRASIL, 2006, p. 1).

Contudo, aos 19 de dezembro de 2019, o G1 - Jornal online publicou que dados estatísticos somente sobre estado de São Paulo, Brasil, mostraram que "casos de feminicídio

\footnotetext{
${ }^{28}$ Disponível em

http://arpenpe.org/?tag=apav
}

aumenta[ra]m $76 \%$ no $1^{\circ}$ trimestre de 2019" (p. 1): crescimento alarmante no percurso de somente três meses. Notem que a matéria não cobre os demais 25 estados do país, e que as regiões norte, nordeste e centro-oeste, onde 0 índice de feminicídio é estarrecedor, não foram contempladas. Isso comprova que lutar contra a cultura do feminicídio de importância cabal no Brasil.

Em contrapartida, de acordo com Nathalia Gherardi (2017), diretora executiva da Equipe Latino-americana de Justiça e Gênero desde 2007, avanços legais substanciais vêm sendo feitos quanto aos direitos da mulher na América Latina:

$\mathrm{Na}$ região da América Latina, avançou-se não somente em marcos normativos, mas também numa dimensão sumamente promissora de sensibilidade social que condena a violência extrema contra as mulheres. Enquadrada numa compreensão holística do dever da devida diligência dos Estados, é necessário abordar com informações melhores e com ferramentas de política pública mais eficazes as outras formas de violência cotidiana que contribuem para sustentar as condições estruturais de discriminação das mulheres nas quais se multiplicam os feminicídios (GHERARDI, 2017, p. 134).

Apesar de inúmeros esforços de organizações, convenções e comitês internacionais, observamos que, tanto 
no México, no Brasil e outros países, a figura sofredora de La Llorona é encarnada em inúmeras mulheres espancadas, estupradas, psicologicamente afrontadas e até mesmo assassinadas. Mais que criar leis, é preciso organizar sistemas de divulgação e conscientização em massa, trabalhos educativos que não somente informem as mulheres mas que principalmente ensinem aos meninos de hoje a serem futuros homens que repensem e fujam da masculinidade tóxica que assola 0 Brasil, México, a América Latina como um todo. Precisamos investir em um mundo melhor não feito de Lloronas, enquanto mártires, mas de Felices, donas dos seus corpos, projetos, altamente qualificadas, com isonomia salarial, ativistas, livres do assédio, do estupro e do feminicídio, não guiadas por telenovelas, mas por teorias feministas que promovam agência e empoderamento.

\section{Referências bibilográficas:}

ALMEIDA, Heloísa B. Consumidoras e heroínas: gênero na telenovela. Revista estudos feministas, v. 15, n. 1, p. 177-192, 2007.

ASHCROFT, Bill et alii. Magic realism. In: Post-colonial studies: The Key
Concepts. London: Routledge, 1998. p. 132-3.

AZZAM, Julie Hakim. The alien within: postcolonial gothic and the politics of home. (Doctoral Dissertation). Pittsburgh: University of Pittsburgh, $2007 . \quad$ Disponível em: https://core.ac.uk/download/pdf/12209 344.pdf. Acesso: 19 dez. 2019.

BASSNETT, Susan. Questões centrais.Trad. Sônia Terezinha Gehring et alii. Estudos de tradução. Porto Alegre: UFRGS, 2005. p. 35-62.

BHABHA, Homi. Narrating the nation. In: BHABHA, Homi (ed.). Nation and narration. London: Routledge, 1995. p.1-7.

BHABHA, Homi. O local da cultura. Trad. Maria Ávila et alii. Belo Horizonte: UFRMG, 2010.

BONNICI, T. Introdução ao estudo das literaturas pós-coloniais. Mimesis, Bauru, v. 19, n. 1, p. 07-23, 1998.

BRASIL. Lei no 11.340. Brasília. Código penal, 2006.

CALAZANS, Janaina de H. C.. O cotidiano fabuloso: os temas recorrentes e o uso de arquétipos dos contos de fada nas telenovelas brasileiras. (Mestrado em Comunicação). Recife: Universidade Federal de Pernambuco, 2003.

CÁLIZ-MONTORO, Carmen. Defying otherness: Chicano geopolitical, literary and historical imprints. In: Writing from the borderlands: a study of Chicano, Afro-Caribbean and Native Literatures in North America. Toronto: Tsar, 2000. p. 3-17.

CAMPEDELLI, Samira Y. A telenovela. São Paulo: Ática, 1985.

CISNEROS, Sandra. El arroyo de La Llorona. In: El arroyo de La Llorona y 
outros cuentos. Trad. Liliana Valenzuela. Neuva York: Vintage Español, 1996. p. 47-61

CISNEROS, Sandra. Woman hollering creek. In: Woman hollering creek and other stories. New York: Vintage Books, 1992. p. 43-56

DERRIDA, Jacques. A escritura e a diferença. São Paulo: Perspectiva, 1995.

FOUCAULT, M. Vigiar e punir. história da violência nas prisões. Petrópolis, RJ: Vozes, 1987.

G1 - Jornal online. A guerra contra as mulheres no México. Rio de Janeiro, 20/08/2019. Disponível em: https://g1.globo.com/mundo/noticia/20 19/08/20/a-guerra-contra-as-mulheresno-mexico.ghtml. Acesso: 03 nov. 2019.

G1 - Jornal online. Casos de feminicídio aumentam $76 \%$ no $1^{\circ}$ 은 trimestre de 2019 em SP; número de mulheres vítimas de homicídio cai. Rio de Janeiro, 19/12/2019. Dispon[ível em: $\quad$ https://g1.globo.com/sp/saopaulo/noticia/2019/04/29/casos-defeminicidio-aumentam-76percent-no10-trimestre-de-2019-em-sp-numerode-mulheres-vitimas-de-homicidiocai.ghtml. Acesso: 19 dez. 2019.

Gazeta digital. Dados do Itamaraty: imigração ilegal causa mais de $50 \%$ das prisões de brasileiros nos EUA. Cuiabá, 19 de dezembro, 2019. Disponível em: https://www.gazetadigital.com.br/editori as/mundo/imigrao-ilegal-causa-maisde-50-das-prises-de-brasileiros-noseua/580779. Acesso: 20 dez. 2019.

GHERARDI, Nathalia. Violência contra as mulheres na América Latina. Trad. Akemi Kamimura. Buenos Aires: Revista Sur, v. 23, n. 24, p. 129-136,
2017. Disponível em: http://sur.conectas.org/wpcontent/uploads/2017/02/12-sur-24por-natalia-gherardi.pdf. Acesso: 14 dez. 2019.

HOOKS, Bell. Sisterhood: political solidarity between women. In: McCLINTON, A. et alii (eds.). Dangerous liasions: gender, nationandpost-colonial perspectives. Minneapolis: University of Minnesota Press, 1997. p. 396-441.

LOPEZ, Mark Hugo et alii. Latinos are more likely to believe in the American dream, but most say it is hard to achieve. Fact Tank: news in the numbers. Washington: Pew Researcher Center, September 11th, 2018. p. 1. Disponível em: https://www.pewresearch.org/facttank/2018/09/11/latinos-are-morelikely-to-believe-in-the-americandream-but-most-say-it-is-hard-toachieve/. Acesso: 19 dez. 2019.

MARQUES, Francisco C. A.; RIBERIO, Rondinele A. A telenovela no Brasil: um gênero por excelência. Cadernos Zygmunt Bauman, v. 6, n.11, p.78-92 2016.

MÉXICO, Estados Unidos de. Congreso General. Cámara de Diputados del $H$. Congreso de La Unión. Ley general de acesso de lasmujeres a una vida libre de violência. Ciudad de México, 2007. Última reforma publicada DOF 13-042018

MINH-HA, Trinh T. Not you/like you: postcolonial women and the interlocking questions of identity and difference. In: McCLINTON, A. et alii (eds.). Dangerous liasions: gender, nationandpost-colonial perspectives. Minneapolis: University of Minnesota Press, 1997. p. 415-419. 
PÉREZ-TORRES, Rafael. The Mestizo Voice. In: Critical uses of race in Chicano culture. Minneapolis: University of Minnesota Press, 2006. 51-82.

RUSHDIE, Salmon. Imaginary homelands: essays and criticism 1981 1991. London \& New York: Granta Books, 1992.

SIMON, Sherry. Revising the boundaries of culture and translation. In: Gender in translation: cultural identity and the politics of transmission. London \& New York: Routledge, 1996. p. 134-167.

SOUZA, Suellen A. de. Leis de combate a violência contra a mulher na América Latina: uma breve abordagem histórica. In: XXVII Simpósio Nacional de História. Anais de Conhecimento Histórico e Análise Social. Natal: ANPUH, 2011. p. 2-18.

SPIVAK, Gayatri. Can the subaltern speak? In: NELSON C. \& GROSSBERG, L. (eds.). Marxism and the interpretation of culture. Basingstoke: Macmillan Education, 1988. p. 271-313.

TODOROV, Tzvetan. Introdução à literatura fantástica. Tradução de Maria Clara Correa Castello. São Paulo: Perspectiva, 1975.
VARGENS, Renato. Maridos evangélicos que batem em suas esposas, 2017. Disponível em: http://renatovargens.blogspot.com/201 2/01/maridos-evangelicos-que-batem- em-suas.html. Acesso: 27 dez. 2019. 